\title{
Perceived Problems on Employment Selection Process: Study on Recent University Graduates
}

\author{
Nugraha Arif Karyanta \\ Doctoral Psychology Program, \\ Universitas Airlangga, Indonesia \\ optimissaja@gmail.com
}

\author{
Pratista Arya Satwika \\ Department of Psychology, Faculty of Medicine, \\ Universitas Sebelas Maret, Indonesia \\ pratista.arsat@gmail.com
}

\author{
Shelly Astriana \\ Department of Psychology, Faculty of Medicine, Universitas Sebelas Maret, Indonesia \\ sellyastriana@gmail.com
}

\begin{abstract}
The challenging condition of economic and job market in Indonesia push graduate university students in a tight competition for the job. This situation often makes job seeking as a hard and long full time job. This study exploring problems perceived by recent university graduates at the time of graduation on employment selection processess. A total number of 207 recent university graduates of a state university in Jawa Tengah Indonesia completed closed-ended and open-ended questionnaire, asking on the problems they perceived of the employment selection processess. The results showed three most low score they perceived in the process of employee selection, that is: competition with higher grade university graduates, interview as part of the selection process, and focus/leaderless group discussion. Results of open-ended questions reveals 8 classifications of problems perceived by the subject. Lack of work experience and the anxiety of job search competition considered as the two most high procentage problems expressed by the subjetcs. The results of this research can then serve as the basis for creating an appropriate career development program for students.
\end{abstract}

Keywords: perceived problems on employment selection, university graduates, job search behavior

\section{INTRODUCTION}

The tight competition in the labor market in Indonesia can be seen from the description of the unemployment rate in Indonesia, as the data released by the Central Bureau of Statistics (2016) follows (Table 1). The table above represents the last three years data released by the Central Bureau of Statistics (2016) on the open unemployment according to the highest education attained based on the National Labor Force Survey 2012-2014. The number of unemployment from university graduates is still very high between $398,298(5,57 \%)$ to $553,206(7.13 \%)$ of the workforce. The trend is even showing significant increase in 2014 after the decline in 2013 in the number of unemployment. It also shows the tight competition for jobs among university graduates in Indonesia.

The tight competition for jobs has impacts on job search behavior and the psychological condition of job seekers (Saks \& Asforth, 1999), such as job search anxiety, self-esteem, and self-efficacy. The process of finding and getting a job is one thing that, unfortunately, has not been studied in college. As a result, once graduated, alumni need their own courses to understand everything about the world of work. More specifically the intricacies of the recruitment selection process itself. The length of the process in job search and alumni ignorance of the process that must be undertaken in job search is one of the things that cause potential problems for job seekers. This research seeks to see the problems that may arise and become fitful from the job seekers in Indonesia.

Research on job search behavior is an important area both for the company and for the perpetrators (Saks \& Ashfort, 1999; Guion \& Highhouse, 2006; Chiriac, Diana, Sălăgean \& Hojbotă, 2013). For the company, the selection process will be the starting point for the future of the company (Edenborough, 2005; Guion \& Highhouse, 2006). The same is true for job seekers, where their earnings in the next few years will largely depend on the success and failure of this process (Chiriac et al., 2013; Saks \& Asfort, 1999). Given the possible consequences of these results in the job search process, it is not surprising that for some people this process will greatly affect the psychological condition, including the possibility of anxiety or other mental disorders.

Human resources are the most important backbone of a company. Recruitment of labor is therefore a very essential process in a company. Emphasizing the basic function of recruitment in today's business environment, Sims (2002) cites Peter F. Drucker, the management guru's who reveals "all organizations compete for the most essential resource: qualified and insightful human resources".

The processes of recruitment and job selection are complex, long and expensive processes. Not only does it affect the future of the company, job seekers also depend on their future from those processes. Various aspects of the selection process are examined and become standard parts of personnel psychology or human resources management (Edenborough, 2005; Guion, 2006; Mangkuprawira, 2003). Nevertheless, the widely used viewpoints for observing this process are more from the company side, and few studies have looked at the impact of this process on the psychological conditions of job seekers in Indonesia. From a variety of keywords related to job search behavior, only 1 article on job interviews the author found (Nasution, 2012) by searching the Indonesia Publication Index or IPI (www.id.portalgaruda.org) as one of the largest publication indexing machine in Indonesia, and the author did not find any other articles related to job search behavior. 
Various studies on job search behavior and psychological impacts resulting from job search process (Saks \& Ashfort, 1999; Wanberg et al., 2001; Rusu et al., 2013) provide explanations on various factors and impacts, such as anxiety (Okay -Somervile
\& Scholarios, 2017; Rusu et al., 2013), stress (da Motta Vega \& Turban, 2014), to the self-regulatory capacity demanded by individuals in the process (Wang, Xu, Zhang \& Fang, 2017).

Table 1

Open Unemployment by Highest Education Attained 2012 - 2014

\begin{tabular}{|c|c|c|c|c|c|c|c|}
\hline \multirow{2}{*}{ No. } & \multirow{2}{*}{ Education } & \multicolumn{2}{|c|}{2012} & \multicolumn{2}{|c|}{2013} & \multicolumn{2}{|c|}{2014} \\
\hline & & February & August & February & August & February & August \\
\hline 1 & No/has not been in school & 126972 & 85374 & 112435 & 81432 & 134040 & 74898 \\
\hline 2 & Not finished primary school & 601753 & 512041 & 523400 & 489152 & 610574 & 389550 \\
\hline 3 & Primary school & 1418683 & 1452047 & 1421873 & 1347555 & 1374822 & 1229652 \\
\hline 4 & Junior high school & 1736670 & 1714776 & 1821429 & 1689643 & 1693203 & 1566838 \\
\hline 5 & Senior high school & 2043697 & 1867755 & 1874799 & 1925660 & 1893509 & 1962786 \\
\hline 6 & Vocational high school & 1018465 & 1067009 & 864649 & 1258201 & 847365 & 1332521 \\
\hline 7 & Diploma I, II, III / Academy & 258385 & 200028 & 197270 & 185103 & 195258 & 193517 \\
\hline 8 & University & 553206 & 445836 & 425042 & 434185 & 398298 & 495143 \\
\hline & Total & 7757831 & 7344866 & 7240897 & 7410931 & 7147069 & 7244905 \\
\hline
\end{tabular}

There are various things in the job search process that can be anxious for job seekers, given the length of the process that the job seeker must go through in the employee selection process, as well as from the various types of tests that the candidate must face. Aamodt (2010) for example reveals several techniques that can be used in the selection process, including: interviews, observation, reference checks, assessment centers, curriculum vitae, psychological tests, and physical skills tests. The different types of tests used have similarities to the common practice or taught in college, but some are quite strange to them, which creates a variety of confusions for the fresh graduates, including general insight into the process of labor selection and detail in each process that must traversed.

In Indonesia the stages of selection that must be undertaken in general include:

1. Selection of administration: consider the portfolio owned by the candidate, usually through a curriculum vitae that is sent along with a cover letter. Conducted by looking at certain conditions such as education, work experience, physical characteristics, GPA and various other parameters. Administrative completeness may also be considered to refuse or provide an opportunity for candidates to follow the next process.

2. Initial interview: discussing the candidate's willingness when faced with certain working conditions, and evaluation of job requirements present in the candidate.

3. Psychological Test: candidates undergo various tests commonly referred to as battery tests that explore various psychological aspects of the candidate. Most of the tests are in the form of paper and pencil test, accompanied by interviews from psychologists, leaderless / focus group discussion and other assignments. The popularity of the assessment center makes the practice of putting more emphasis on standardized written tests shifting to various activities in the assessment center.

4. Final evaluation: evaluate the results of a series of tests and interviews to determine whether the candidate is accepted or rejected. This is usually followed up with medical tests for eligible candidates. The determination of recommendations on candidates may use mechanical, clinical or mixed methods of mechanical - clinical or clinical mechanical.

5. The final notification and interview: the accepted candidate is called to the final interview, usually an interview from the user whether it is from the division head where the candidate will be assigned, the board of directors, or the HRD part of the company. Some information will usually be accepted by the candidate, such as various company policies, salary, placement and so forth.

6. Acceptance: the candidate receives a decision about being accepted to be part of the company, orientate to the company, and start work.

Selection of the wrong candidate in the process will have a fatal impact on the company: poor performance, increased demand for training, demotivation for other employees, high absenteism, etc. (Torrington, Hall \& Taylor, 2008). These demands have led to a growing number of methods employed by companies to ensure that the selected candidate is the person most capable of meeting job demands and best suited to work groups and organizational culture. Implications for job seekers, this means that the process that needs to be exceeded in the selection of work becomes increasingly heavy and stressfull. In practice, usually the more bonafide a company then the demands and selection process of the candidate is also getting tighter.

For university graduates in Indonesia, the obstacles faced will be more severe because of the tight competition among graduates in obtaining jobs. High unemployment rates from universities can not be matched by economic growth, so it is not surprising that many of the college graduates choose to use their high school diploma when applying due to everqualification. Not to mention the fact that the success in the competition process for this job is not solely because of the competence, but there are also various other factors. Even the tight competition of 
prospective workers in Indonesia often leads to 10: $3: 2$, where from 10 job seekers in Indonesia there are only 3 vacancies. Of these 3 vacancies, only two can be filled, as one more chance is filled by connections, references, relatives, relatives or foreign workers. This research seeks to explore the perceptions of fresh graduate job seekers on the problems they face to compete for jobs.

\section{Study Participants}

\section{METHODS}

The subjects in this study were fresh graduates from a state university in Central Java Indonesia in 2017. A total of 207 respondents represented various faculties, consisting of 70 men (33.82\%) and 137 women $(66.18 \%)$. In terms of participation in the organization during schools, 166 respondents $(80.19 \%)$ reported having attended the activities in student organizations, and $41(19.81 \%)$ did not participate in the organization's activities.

\section{Measurement}

Instruments used to collect data consists of 9 items closed - ended questions and one open ended questions. The nine items covered the respondents' assessment of their readiness to face various stages of job search, including to face competition from other college graduates with higher or lower grade. While open ended questions employed to explore the various obstacles they may face in the competition process to get a job.

Quantitative data are analyzed using descriptive statistics to compare assessments of their ability / readiness in dealing with various stages of job search. Qualitative data analyzed using the steps recommend by Cresswell (2014) include: (1) processing and preparing data; (2) reading the entire data; (3) analyze more detail by coding data; (4) implementing the coding process to describe the settings, the people, the categories, and the themes to be analyzed; (5) presenting the themes back into the narrative / qualitative report; and (6) interpret the data. Data were analyzed by 3 people from the research team to ensure inter-rater relibility of each category.

\section{RESULT}

\section{Readiness for the selection processes}

The results of the analysis of nine items closed - ended questions, which is the result of self-assessment of knowledge and ability to face the labor recruitment process is presented in Table 2 . The table shows competitiveness with candidates from other universities with higher grades as the lowest score $(=3.25)$, followed by interview skills $(=3.35)$, and ability to face group discussions $(=3.37)$ as the three lowest scores, while under the overall scoring score $(=3.43)$. While the other aspects are above the overall scoring scores, ie the consecutive of the lowest are: the ability to deal with psychotest $(=3.51)$, the ability to write job application letter and curriculum vitae $(=3.52)$, knowledge of the terms and job application $(=3.70)$, knowledge related to job vacancy information $(=3.71)$, and the highest is the ability to compete with candidates from other universities with lower grades $(=3.80)$.

Table 2

Readiness for the Selection Processes

\begin{tabular}{lcc}
\hline \multicolumn{1}{c}{ Aspek } & Skor Total & Mean \\
\hline Knowledge of the whole process of labor recruitment & 709 & 3,43 \\
Knowledge related job vacancy information & 768 & 3,71 \\
Pengetahuan tentang syarat dan cara melamar pekerjaan & 766 & 3,70 \\
Knowledge of terms and how to apply for a job & 729 & 3,52 \\
Ability to deal with psychotest & 726 & 3,51 \\
Ability to face interview & 694 & 3,35 \\
Ability to face group discussions & 698 & 3,37 \\
Ability to compete with candidates from other universities with lower grades & 786 & 3,80 \\
Ability to compete with candidates from other universities with higher grades & 673 & 3,25 \\
\hline
\end{tabular}

It is interesting that the highest scores and the lowest scores are in the same category, that is competition with other candidates. This gives an indication that fresh graduate has a perception of competition as the main determinant of success in job search. They perceive alumni from other universities with higher grades as the greatest threat in the job search process, or when dealing with competitors who are perceived as superior.

The next two most important aspects are interviews and group discussions. These two aspects are aspects that require subjects to express themselves, show their thoughts, feelings and abilities to others. Interviews are becoming more of a concern for the subject, perhaps because the faces in this interaction are the superior figures perceived as determinants of their fate, even though the actual interview is only part of the process that will determine their success in the job search process. Nevertheless, the "concern" of group discussion as the third lowest score provides reinforcement of what has been said above, that it seems that the research subjects feel that they have difficulties in expressing themselves and dealing with others, even when it is peers or equal people.

\section{Problems in the Selection Processes}

Table 3 shows the tabulation of subject answers, which represent statements of their concern at each stage of labor recruitment. Although the number of subjects is 207, the unit of analysis in this open questionnaire is the unit of meaning expressed by the subject, which illustrates the extent to which their concerns with the aspects. Thus, a subject may suggest more than one unit of analysis. In this first point, there are 280 statements proposed by research subjects, which are then classified using a thematic analysis model. 
Table 3

Problems in the Selection Processes Perceived by The Subjects

\begin{tabular}{|c|c|c|}
\hline Respons & Amount & Percentage \\
\hline \multicolumn{3}{|l|}{ INSTITUTIONAL } \\
\hline University reputation & 6 & $2,14 \%$ \\
\hline Accreditation of study program & 3 & $1,07 \%$ \\
\hline Background of study program & 15 & $5,36 \%$ \\
\hline Alumni Association & 2 & $0,71 \%$ \\
\hline \multirow{2}{*}{\multicolumn{3}{|c|}{$9,29 \%$}} \\
\hline & & \\
\hline Height / weight & 7 & $2,50 \%$ \\
\hline Color blind & 1 & $0,36 \%$ \\
\hline Medical check up & 3 & $1,07 \%$ \\
\hline Age & 2 & $0,71 \%$ \\
\hline Other physical characteristic & 3 & $1,07 \%$ \\
\hline Appearance & 3 & $1,07 \%$ \\
\hline \multicolumn{3}{|r|}{$6,79 \%$} \\
\hline \multicolumn{3}{|c|}{ PERSONAL CHARACTERISTICS RELATED INSTITUTIONS } \\
\hline GPA & 3 & $1,07 \%$ \\
\hline Work experience / apprenticeship & 32 & $11,43 \%$ \\
\hline Foreing language (english) & 24 & $8,57 \%$ \\
\hline GRE (TPA) & 2 & $0,71 \%$ \\
\hline Organizational experiences & 3 & $1,07 \%$ \\
\hline Total & 64 & $22,86 \%$ \\
\hline \multicolumn{3}{|l|}{ RELATED TO REKRUTMEN PHASE } \\
\hline Psychotest & 7 & $2,50 \%$ \\
\hline Interview & 19 & $6,79 \%$ \\
\hline Public speaking \& presentation & 4 & $1,43 \%$ \\
\hline World of work horizon & 19 & $6,79 \%$ \\
\hline Writing curriculum vitae & 3 & $1,07 \%$ \\
\hline 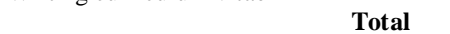 & 52 & $18,57 \%$ \\
\hline \multicolumn{3}{|l|}{ PERSONAL } \\
\hline Softskill \& character & 7 & $2,50 \%$ \\
\hline Self confidence & 9 & $3,21 \%$ \\
\hline Lack of ambition \& achievement & 3 & $1,07 \%$ \\
\hline Difference career orientation with parents & 3 & $1,07 \%$ \\
\hline competition & 29 & $10,36 \%$ \\
\hline Abilities / skills & 17 & $6,07 \%$ \\
\hline Communication skills & 4 & $1,43 \%$ \\
\hline Less understanding of interest & 4 & $1,43 \%$ \\
\hline Lack of self branding strategy & 1 & $0,36 \%$ \\
\hline Achievement & 1 & $0,36 \%$ \\
\hline Do not have work channel & 1 & $0,36 \%$ \\
\hline Lack of money & 1 & $0,36 \%$ \\
\hline Do not have experrience on work test yet & 1 & $0,36 \%$ \\
\hline (5) & 81 & $28,93 \%$ \\
\hline \multicolumn{3}{|l|}{ EKSTERNAL } \\
\hline Nepotism on selection process & 19 & $6,79 \%$ \\
\hline Work location & 4 & $1,43 \%$ \\
\hline A sudden \& remote test call & 2 & $0,71 \%$ \\
\hline \multirow[t]{2}{*}{ Work environment } & 1 & $0,36 \%$ \\
\hline & 26 & $\mathbf{9 , 2 9 \%}$ \\
\hline NOT HAVING PROBLEMS & 11 & $3,93 \%$ \\
\hline \multicolumn{3}{|l|}{ OTHERS } \\
\hline God does not bless & 1 & $0,36 \%$ \\
\hline
\end{tabular}

The above data show 8 classification of answers, namely: (1) institutional, including university reputation, accredited study program, background of study programs, and alumni association, by $26 \%$; (2) physical, covering height \& weight, color blindness, health test, age, other physical characteristics, and appearance, of $6.79 \%$; (3) personal characteristics related to the institution, including GPA, work experience \& internship, foreign language (UK), TPA, and organizational experience, amounted to $22.86 \%$; (4) related to recruitment stages, including psychology, interview, presentation \& public speaking, work world insight, and CV writing, amounting to $18.57 \%$; (5) personal factors, including softskill \& character, self-confidence, lack of ambition \& achievement, family conflict, competition, ability / skill, communication skills, lack of understanding of interest, how self-banding, achievement, lack of channels, lack of funds, and none test experience, amounting to 28.93\%; (6) external factors, including company nepotism, work location, sudden and distant test calls, and work environment, amounting to $9.29 \%$; (7) does not exist or does not state the existence of the problem, amounting to $3.93 \%$; and (8) others, by $0.36 \%$.

In institutional aspect, background of majors become main concern from research subject. This is mainly related to the response that the department has a narrow job, or has too many rivals. The university's reputation is also one of the concerns, which also 
implies the "apprehensiveness" of the alumni in the workplace competition.

Aspects of personal characteristics related to the institution show individual aspects related to the program in university, ie GPA, foreign language skills, work experience, and organizational experience. Work experience is the highest concern of the respondents due to the fact that they are fresh graduates, but on the other hand there are many job vacancies that require experience. Another thing that concerns on this aspect is the ability of foreign languages, including TOEFL, but at most is the ability to communicate in foreign languages, especially English.

In aspects related to the recruitment process, interviews are seen as the most attention aspect of alumni. The amount is balanced with the alumni's overall insight into the labor recruitment process. From the various respondents' answers, if the overall insights indicate confusion from various labor recruitment processes, the interviews show more as a single aspect in the process of employment recruitment. So it can be concluded that from the various stages of recruitment, interviews are the stage of the most attention.

On the personal aspect, competition is part of the concern of the subject who gets the most attention. In this section, concerns over competition split into competition as a whole, and competition with alumni from other higher-grade universities. Uncertainty about self-ability to be the next point to note, followed by confidence and character.

One of the interesting things that respondents say are those that are related to external conditions, including change nepotism, work location, work environment, and abrupt and distant test calls. In this aspect, nepotism turns out to be the most worrying point for students. This nagotism means that the acceptability of a person is more influenced by factors beyond the ability, namely the existence of networks with "insiders" that make the competition to be running unfairly.

Next is the "no" aspect which means that the subject has no particular concern about the job search process. In contrast to other points, this non-existent aspect is individual, meaning that the number 11 indicates that there are 11 people who say no or do not write anything.

\section{DISCUSSION}

Some of the findings in this study can be used to assist universities in developing programs that match the characteristics of the problems faced by job seekers. Following what Ang (2015) discloses, universities should give higher emphasis to graduate employability or how graduates can work well on demand from the job market. Quality must take precedence over quantity, rather than emphasis on the academic achievement index or any other quantity measure.

Findings on the 3 lowest scores from the closed-ended questionnaire above, competition with candidates from other universities with higher grades, interview readiness, and group discussions implies several things. First, it implies the unpreparedness of university graduates in the fierce competition of the labor market. The more open the world in the labor market is thus still a threat to Indonesia's educated workforce. Governments and universities need to make various efforts to increase the competitiveness of the university graduate's advantage in the labor market. Secondly, the three lowest scores as a whole also show a feeling of inferiority from the alumni. They feel less able to compete, and experience barriers in expressing themselves both to the authority figure represented by the interviewer, but also to the peers.

$\mathrm{Yu}$ (2017) conducted a study in China on how elite college graduates have a competitive advantage over non-elite colleges. Alumni from elite colleges have 1.7 times greater chances to be accepted in the public sector such as civil servants and state owned companies. The quality and credibility of universities is thus an advantage for alumni in the work competition. The implication is that universities need to make better efforts to build that credibility. On the other hand, building the perception and attribution of university residents as world elites especially in the job market is a separate work.

This requires mental toughness to see ourself as a valuable, useful and competent citizen of the world, as well as the ability to express and demonstrate that ability. The feeling of inferiority and the inability to express themselves is a threat in the employment selection process because it makes the candidate appear less able to display positive attitudes, positive thinking, to the judgment of self-appearance that tend to be less. The lack of such characteristics influences the assessor assessment of the leadership aspect, tends to be a follower because of frequent self-doubt, lack of courage to express the mind, lack of initiative, and therefore becomes less able to be a problem solver, even though it is actually capable. The university therefore needs to build a kind of pre-job training program that also provides attribution as the world's elite. Some of the problems summarized from open-ended questionnaire questions provide a clearer picture of the programs that can be made to prepare graduates.

The program to provide horizon of how the selection process of the workforce so that alumni can display their own potential optimally in selection process certainly can not guarantee that any alumni then will definitely get the job he wants. However the job market is a competition, and which can be done later, quoting Ang (2015) is as saying "You can lead a horse to water, but you can not make it drink." Several studies have shown that pre-job training can prepare students to be better able to face the selection process. McCorckle, Alexander \& Dirik (2013) in his research for example concluded that the self-marketing plan project is able to provide marketing skills for students who will be useful throughout the career of the student.

Albeit its limitations, this study has offered useful preliminary data on the problems perceived by the recent graduate university. Findings in this study can be used as a foundation for the university to create a more solid pre-job training program based on the real problems felt by the alumni. 


\section{CONCLUSION}

First, from the institutional aspect, as quoted by $\mathrm{Yu}$ (2017) above, the reputation of the university has a great influence on the alumni. The university needs to have a road map in the development of student competence that shows the distinctive characteristics that become the excellence of alumni in the labor market, and strengthens the competence. In addition, due to anxiety from alumni that their majors have narrow jobs, each study program needs to have guidance on potential career directions in the labor market.

Second, in relation to the physical demands of some jobs, it is an inevitable thing because certain types of work do have distinctive demands. However related to physical appearance, pre-job programs also need to provide input on how to present themselves optimally in the recruitment process.

Third, in relation to the most expressed work of unrest expressed by the alumni, the university needs to strengthen the internship program so that it is better able to bridge the skills required by the industrial world, as suggested by Ang (2015). Foreign language skills are also expected to be strengthened, not only in academic goals, but also for discussion and communication in general. This includes providing input on how to write the curriculum vitae and portfolio to attract the company.

Fourth, consistent with the findings of closed-ended questions, interview seems to be a process of selection in that is the source of anxiety from alumni. Training to face the job interview process needs to be a priority in pre-job training so as to make alumni able to present themselves optimally. This should be coupled with the development of self-esteem because it seems that anxiety over the interview process is related to the self-esteem of the candidate. Despite the emphasis on interviews, other processes as a whole need to be addressed so as to broaden the horizons of job selection and clarify the field of competition.

Fifth, the competition is the sub-classification that becomes the highest respondent anxiety after work experience. As stated above, the university needs to prepare supplies so that alumni have competitive advantage in the workplace. The process of pre-job training also needs to provide insight and strengthening of the alumni's ability to survive and succeed in competing. Pre-job training programs also need to provide reinforcement as well as how to present some of the main characteristics that they have to highlight their strengths.

Sixth, nepotism turns out to be a finding as a characteristic that still seems to be going on in the labor recruitment process in Indonesia. Governments, companies, including those relating to the recruitment process must improve themselves to be more disciplined in carrying out the employee recruitment process in a clean, transparent, professional and fair manner. This will ensure that the job will be filled by the right candidate. Pre-job training programs also need to provide input on the use of the channels they have to obtain information about existing jobs.

\section{REFERENCES}

[1] Aamodt, M. G. 2010. Industrial/Organizational Psychology: An Applied Approach. Belmont: Wadsworth.

[2] Ang, M. C. H. 2015. Graduate Employability Awareness: A Gendered Perspective. Procedia - Social and Behavioral Sciences, 211, 192-198.

[3] Central Beureu of Statistics. 2016. Pengangguran Terbuka menurut Pendidikan Tertinggi yang Ditamatkan 2004-2014. Retrieved December 9, 2016, from http://www.bps.go.id/linkTabelStatis/view/id/972.

[4] Cresswell, J. W. 2014. Research Design, Pendekatan Kualitatif, Kuantitatif dan Mixed. Yogyakarta: Pustaka Pelajar.

[5] daMotta, V., Serge, P., \& Turban, D. B. 2014. Are Affect and Perceived Stress Detrimental or Beneficial to Job Seekers? The Role of Learning Goal Orientation in Job Search Self-Regulation. Organizational Behavior and Human Decision Processes, 125(2014), 193203.

[6] Devonshire-Ellis, C., Scott, A., and Woolard, S. 2011. Human Resources in China. Berlin: Springer.

[7] Edenborough, R. 2005. Assessment Methods in Recruitment, Selection and Performance: A manager's guide to psychometric testing, interviews and assessment centres. London: Kogan Page.

[8] Guion, R. M. \& Highhouse, S. 2006. Essentials of Personnel Recruitment and Selection. New Jersey: Lawrence Erlbaum.

[9] Heatherton, T. F., and Wyland, C. L. 2003. Assessing Self-Esteem. In Lopez, S. J., and Snyder, C. R. (Ed)., Positive Psychological Assesment: A Handbook of Models and Measures. Washington D.C. American Psychological Association.

[10] Karyanta, N. A. 2012. Efektivitas Program Intervensi Terapi Puisi untuk Mengembangkan Self-Esteem pada Penyandang Tuna Daksa. Thesis. Bandung: UNPAD.

[11] Lawson, K. 2006. The Trainers Handbook. London: Pfeiffer.

[12] Mangkuprawira, S. 2003. Manajemen Sumber Daya Manusia. Jakarta: Ghalia.

[13] McCorckle, A., \& Dirikel. 1992. Developing Self-Marketing Skills for Student Career Success. Journal of Marketing Education, 14, 57-64.

[14] Mruk, C. J. 2006. Self-Esteem Research, Theory and Practice: Toward a Positive Psychology of Self-Esteem. New York: Springer Publishing Company.

[15] Nasution, H. B. 2012. Kecemasan Berkomunikasi antar Pribadi dalam Tes Wawancara Kerja. Jurnal Ilmu Komunikasi Flow, (1)1.

[16] Okay-Somerville, B., and Scholarios, D. 2017. Job Search Anxiety and Perceived Barriers to Labour Market Entry. European Association of Work and Organizational Psychology Congress, Dublin, Ireland, 17-20 May.

[17] Rusu, A., Chiriac, Diana C., Sălăgean, N. \& Hojbotă, A. M. 2013. Job search self-efficacy as mediator between employment status and symptoms of anxiety. Romanian Journal of Applied Psychology, 15(2), 69-75.

[18] Saks, A. M., \& Asforth, B. E. 1999. Effects of Individual Differences and Job Search Behaviors on the Employment Status of Recent University Graduates. Journal of Vocational Behavior, 54, 335 - 349.

[19] Torrington, D., Hall, L., and Taylor, S. 2008. Human Resource Management, Seventh Edition. Essex: Prentice Hall. 
[20] Wanberg, C. R., Kammeyer-Mueller, J. D., \& Shi, K. 2001. Job Loss and the Experience of Unemployment: International Research and Perspectives. In Anderson, N., Ones, D. S., Sinangil, H. K. \& Viswesvaran, C., (Ed)., Handbook of Industrial, Work and Organizational Psychology. London: Sage Publications.

[21] Wang, L., Xu, H., Zhang, X., \& Fang, P. 2017. The Relationship between Emotion Regulation Strategies and Job Search Behavior among Fourth-Year University Students. Journal of Adolescence, 59, 139-147.

[22] Yu, Li. 2017. Did Better Colleges Bring Better Jobs? Estimating the Effects of College Quality on Initial Employment for College Graduates in China. Current Issues in Comparative Education (CICE), 19(2). 